\title{
ANALISIS PENGARUH GROWTH TERHADAP PROFIT PADA PERUSAHAAN MANUFAKTUR TERBUKA DI INDONESIA: ANALSIS MODEL PANEL DATA DINAMIS
}

\author{
Aditya Guntur Prakasa ${ }^{1}$, Firmansyah ${ }^{2}$
}

\author{
Departemen IESP Fakultas Ekonomika dan Bisnis Universitas Diponegoro \\ Jl. Prof. Soedharto SH, Tembalang Semarang
}

Adityagunturprakasa@gmail.com

\begin{abstract}
Growth will affect profitability of a firm. There is ongoing debate about how growth will affect profit both theoritically and empirical results. Classical hypothesis predict growth will affect profit positively. Growth can improve firm profitability because the effect from economies of scale and the learning curve effect that makes the production process and the cost of production become more efficient. Behavioral hypothesis predict growth will affect profit negatively because of principal agent problem, managerial constraints, penrose effect or diseconomies of scale. The objective of this study is to examine the effect of growth to profit based on the argument between Classical hypothesis and behavioral hypothesis.

This study used dynamics panel data with generalized method of moments (GMM) as estimator. This study observed 82 publicly listed manufacturing firm in Indonesia consist of nine periods from 2009 to 2018 resulting in 656 observations. Empirical result shows that growth will affect profit negatively. Thus, prove the behavioral hypothesis that predict negative influence of growth to profit.
\end{abstract}

Keywords: Profit, Growth, Publicly listed manufacturing company, Dynamics Panel Data, Indonesia

JEL Classification: two-digit number classification of Journal of Economic Literature (JEL).

\section{PENDAHULUAN}

Bagaimanakah growth yang dialami oleh perusahaan akan mempengaruhi profit perusahaan? Seperti yang akan di diskusikan pada bagian tinjauan pustaka, secara teoritis, terjadi perdebatan mengenai pengaruh growth kepada profit. Ada yang berpendapat bahwa growth memberikan pengaruh negatif kepada profit dan ada juga yang berpendapat bahwa growth akan memberikan pengaruh positif kepada profit. 
Terjadinya perdebatan teoritis mengenai pengaruh growth kepada profit, membuat hasil empiris lah yang dapat menentukkan bagaimana pengaruh growth kepada profit. Untuk itu, pada penelitian ini kami akan memeriksa secara empiris bagaimana pengaruh growth kepada profit.

Penelitian ini bertujuan untuk mengkonfirmasi hasil analisis empiris mengenai pengaruh growth kepada profit pada perusahaan manufaktur terbuka di Indonesia. Dengan menggunakan analisis model panel data dinamis dan metode generalized method of moment (GMM) sebagai estimator untuk mendapatkan hasil yang tidak bias.

\section{TINJAUAN PUSTAKA}

Analisis mengenai growth perusahaan merupakan salah satu topik yang penting untuk diteliti. Menurut Carrizosa (2006), ada beberapa alasan mengapa growth perusahaan menjadi salah satu topik yang penting untuk diteliti. Alasan pertama adalah karena growth perusahaan menggambarkan bagaimana perusahasan ber-evolusi dan berperilaku di pasar, kedua hal tersebut nantinya akan berkaitan dengan bagaimana perusahaan bisa survive di dalam suatu industri. Alasan kedua, growth perusahaan mempunyai efek terhadap employment dan juga pertumbuhan ekonomi. Dan alasan ketiga adalah growth perusahaan bisa menggambarkan bagaimana konsentrasi pasar di dalam suatu industri. Para ekonom mencoba mencari tahu mengenai alasan mengapa suatu perusahaan dapat mengalami growth dan juga apakah sumber yang menyebabkan growth perusahaan.

Menurut Carrizosa (2006), tidak ada teori yang secara utuh menganalisis penyebab, akibat atau evolusi dari growth perusahaan. Hal ini dikarenakan kompleksnya definisi para ekonom mengenai growth perusahasan dan juga definisi perusahasan yang berbeda beda. Kompleksnya definisi growth sendiri nantinya akan melahirkan beberapa perspektif dan prediksi yang berbeda mengenai teori growth perusahaan. Untuk itu, Carrizosa membagi literatur teori growth perusahaan menjadi empat pendekatan, yakni pendekatan klasik, pendekatan behavioral, pendekatan stokastik dan juga pendekatan learning and selection. Keempat pendekatan ini adalah hasil dari beberapa teori yang diungkapkan dalam usaha untuk memberikan Analisa mengenai growth perusahaan.

Di dalam penelitian ini, pendekatan growth yang akan dibahas hanya ada dua, yakni pendekatan klasik dan juga pendekatan behavioral. Hal ini dikarenakan kedua pendekatan tersebut membahas bagaimana pengaruh growth kepada profit dan kedua pendekatan tersebut mempunyai prediksi yang berbeda mengenai bagaimana growth akan mempengaruhi profit perusahaan.

Pendekatan klasik dapat dilihat di dalam theory of the firm. Theory of the firm adalah sekumpulan teori yang digunakan untuk menjelaskan perilaku perusahaan di dalam kegiatan ekonomi (Chan \& Murphy 2019). Di dalam theory of the firm, dijelaskan bagaimana perilaku perusahaan untuk memaksimalkan profit-nya. Dari mulai bagaimana perusahaan memilih input, kurva biaya perusahaan, hingga bagaimana perusahaan menentukkan tingkat harga dan output yang memaksimalkan 
profit pada struktur pasar dimana perusahaaan berada. Teori ini dikembangkan oleh para ekonom klasik dan neoklasik.

Growth dibahas di dalam theory of the firm dalam bentuk internal economies dan juga external economies yang diungkapkan oleh Alfred Marshall (Brue and Grant 2007). Internal economies adalah efisiensi biaya yang terjadi ketika perusahaan sudah mengalami growth. Ketika perusahaan sudah menjadi lebih besar, maka perusahaan dapat menikmati economies of scale dari produksi massal. Economies of scale adalah ketika biaya perusahaan untuk memproduksi output menjadi lebih rendah dan perusahaan dapat memproduksi output dalam jumlah yang lebih banyak dengan biaya yang lebih rendah. External economies adalah penurunan biaya input dan biaya transportasi yang terjadi karena industri secara keseluruhan sudah mengalami growth, sehingga biaya input dan biaya transportasi bisa lebih rendah.

Konsep growth yang di bahas di dalam theory of the firm kaum klasik dan neoklasik memprediksikan bahwa growth akan memberikan pengaruh positif kepada profit perusahaan. Pengaruh positif tersebut disebabkan oleh economies of scale dan efek dari learning curve yang akan membuat biaya produksi perusahaan menjadi lebih efisien, sehingga perusahaan bisa beroperasi pada tingkat biaya yang lebih efisien (Gupta, 1981). Dan ketika perusahaan dapat menekan tingkat biaya, maka akan memungkinkan perusahaan untuk mencapai tingkat profit yang lebih tinggi lagi.

Pada perkembangannya, banyak ekonom yang tidak puas dengan penjelasan mengenai firm growth yang diungkapkan kaum klasik. Pendekatan behavioral muncul sebagai bentuk kritik terhadap growth yang diungkapkan oleh kaum klasik di dalam theory of the firm. Beberapa ekonom yang mengkritik theory of the firms neoklasik adalah Baumol, Marris dan Penrose. Para ekonom tersebut berpendapat bahwa theory of the firm neoklasik gagal menjelaskan perilaku perusahaan pada dunia modern, hal ini karena analisis theory of the firm dibasiskan pada perusahaan yang ada pada abad ke 19, sehingga perilaku dan konsep analisis dibangun dari studi empiris dan kegiatan perusahaan pada jaman itu (Lipczynski 2005). Sedangkan pada abad ke 20, perusahaan sudah menjadi organisasi yang semakin kompleks dan perilakunya dalam memaksimalkan profit akan berbeda.

Perusahaan pada dunia modern berbeda dengan perusahaan pada abad ke 19 . Perusahaan yang ada pada abad ke 19 lebih banyak merupakan perusahaaan dengan skala kecil menengah dimana para entrepreneur atau owner langsung lah yang menggerakkan semua kegiatan perusahaan untuk memaksimalkan profit. Perusahaan pada dunia modern sudah menjadi sebuah organisasi yang semakin kompleks, dimana semua kegiatan perusahaan dalam rangka memaksimalkan profit-nya tidak lagi bergantung langsung kepada entrepreneur atau owner. perusahaan mulai memanggil tenaga ahli baru untuk menjalankan kegiatannya. Tenaga ahli ini adalah manager yang ahli dalam bidangnya (Lipczynski 2005). Para manager ini nantinya akan menentukan bagaimana kegiatan perusahaan dalam memaksimalkan profit. 
Munculnya manager sebagai agen baru dalam pengambilan keputusan perusahaan, memunculkan teori managerial theories of the firm yang menganalisis bagaimana perilaku manager di dalam memaksimalkan profit perusahasan. Pendekatan behavioral mendasarkan analisisnya pada teori teori yang diungkapkan di dalam managerial theories of the firm. Beberapa ekonom yang mengembangkan teori ini adalah William Baumol (1958), Edith Penrose (1959) dan Robert Marris (1964). Managerial theories of the firm memprediksikan bahwa growth akan memberikkan pengaruh negatif kepada profit karena adanya principal agent problem, Batasan Manajerial dan terjadinya penrose effect.

Principal agent problem yang diungkapkan Baumol menyatakan bahwa perilaku manager bisa saja menyimpang dari memaksimalkan profit. Di dalam teori Baumol sales revenue maximization, Baumol menggambarkan bahwa manager bisa saja lebih memilih untuk memaksimalkan sales. Ketika manager memilih untuk memaksimalkan sales, maka pemilihan tingkat output yang akan diproduksi oleh perusahasahaan bisa jadi berada di luar profit maksimal. Penrose effect terjadi ketika para manager perusahaan terlalu fokus untuk melakukan strategi growth sehingga biaya perusahaan membengkak dan menyebabkan profit perusahaan berkurang. Marris memprediksikkan bahwa batasan manajerial akan hadir ketika perusahaan mengalami growth yang terlalu cepat.

Kaum klasik dan kaum behavioral mempunyai prediksi yang berbeda mengenai bagaimana growth akan mempengaruhi profit. pendekatan klasik memprediksikan growth akan memberikan pengaruh positif kepada profit karena adanya economies of scale dan juga efek dari learning curve yang nantinya membuat proses produksi perusahaan menjadi lebih efisien dan biaya yang lebih efisien sehingga profit perusahaan akan lebih tinggi. Sedangkan kaum behavioral memprediksikan growth akan memberikan pengaruh negatif kepada profit perusahaan karena terjadinya principal agent problem, Batasan manajerial atau penrose effect. Ditengah perdebatan teori tersebut, maka bergantung kepada penelitian empiris untuk membuktikkan kedua hipotesis yang bertentangan tersebut.

Ada beberapa penelitian empiris yang meneliti mengenai pengaruh growth kepada profit. Cowling (2004), dengan menggunakan regresi OLS dan 2SLS meneliti hubungan antara profit dan growth pada perusahaan yang ada di Inggris raya dalam kurun waktu (1991 - 1993), hasil penelitian Cowling menunjukkan bahwa growth akan memberikan pengaruh positif kepada profit perusahaan dalam jangka Panjang. Goddard, Molyneux, and Wilson (2004), meneliti 583 bank yang ada di Eropa dalam kurun waktu (1992-1998). Dengan menggunakan regresi OLS dan juga Generalized Method of Moments (GMM), menunjukkan bahwa growth perusahaan akan memberikan pengaruh negatif kepada profit perusahaan. Coad (2007), meneliti 8045 perusahaan manufaktur di Perancis dan menunjukkan bahwa growth memberikan efek positif kepada profit. Coad (2010) melakukan penelitian dengan menggunakan data yang sama yang digunakan pada tahun 2007 dan menemukan hasil yang sama, yakni growth akan memberikkan pengaruh positif kepada profit perusahaan. Coad, Rao, and 
Tamagni (2011) melakukan penelitian pada perusahaan manufaktur di Italia. Dan hasil temuannya pun tetap konsisten, yakni growth memberikan pengaruh positif kepada profit.

Uji empiris yang paling terkini dilakukan oleh Jang \& Park (2011) dan juga Lee (2014). Jang \& Park (2011) melakukan uji empiris pada 5812 restaurant yang ada di Amerika Serikat dalam kurun waktu 1978 - 2007. Metode GMM digunakan untuk menghasilkan estimasi yang tidak bias dan konsisten. Hasil uji empiris Jang \& Park menunjukkan bahwa growth memberikan pengaruh negatif terhadap profit. Lee (2014), meneliti 606 perusahaan yang terdaftar di bursa efek Korea Selatan dalam jangka waktu 1999 sampai 2008. Hasi uji empiris penelitian Lee menunjukkan growth memberikan pengaruh positif kepada profit.

Hasil penelitian empiris menunjukkan hasil yang berbeda beda. Coad (2007), Coad (2010),Coad, Rao, and Tamagni (2011) menunjukkan hasil empiris yang mendukung hipotesis kaum klasik, yakni pengaruh positif dari growth kepada profit. (Cowling (2004), Lee (2014) juga menunjukkan hasil yang sama seperti Coad. Sedangkan, Goddard, Molyneux, and Wilson (2004), Jang \& Park (2011) justru menunjukkan hasil empiris yang mendukung hipotesis kaum behavioral yang memprediksi pengaruh negatif dari growth kepada profit. Menurut Lee (2014), berbedanya hasil uji empiris bisa jadi disebabkan oleh berbedanya model dan alat uji ekonometrika yang digunakan oleh peneliti, dan juga keadaan institusional dan makroekonomi dan keadaan indusri yang berbeda beda di setiap negara yang menjadi basis penelitian empiris.

\section{METODE PENELITIAN}

\section{A. Definisi Variabel}

Ada dua acara untuk mengukur growth perusahasan, yakni dengan menggunakan absolute growth dan proportional growth, pada penelitian ini, proportional growth akan digunakan untuk mengukur growth perusahaan karena proportional growth dianggap lebih bebas akan asalah heterokedastisitas (Coad \& Hölzl 2012). Growth di proxy-kan dengan sales growth dan employee growth, menurut Carrizosa (2006), sales dan employee growth menggambarkan proses internal perusahaan dan juga datanya tersedia sehingga kedua variabel tersebut adalah variabel yang cocok sebagai indicator growth. Proportional growth perusahaan ditunjukkan dalam rumus sebagai berikut:

- $\quad$ Sales Growth $_{i, t}=\log \left(\right.$ Sales $\left._{i, t}\right)-\log \left(\right.$ Sales $\left._{i, t-1}\right)$

- Employee Growth $_{i, t}=\log \left(\right.$ Employee $\left._{i, t}\right)-\log \left(\right.$ Employee $\left._{i, t-1}\right)$

Return on sales digunakan sebagai proxy dari profit, return on sales adalah rasio keuangan yang digunakan untuk mengukur seberapa efisien perusahaan untuk menghasilkan profit dari penjualannya. Return on sales dapat dihitung sebagai berikut: 
Return on Sales $i, t=\frac{\text { Netincome }_{i, t}}{\text { Netsales }_{i, t}} \times 100$

\section{B. Jenis dan Sumber Data}

Data yang digunakan dalam penelitian ini adalah data sekunder. Data dalam penelitian ini dikumpulkan melalui Bloomberg Financial Lab FEB Universitas Diponegoro untuk memperoleh data dari laporan keuangan perusahaan manufaktur yang terdaftar di bursa efek Indonesia.

Penelitian ini menggunakan data panel, dengan sampel 82 perusahaan manufaktur terbuka di Indonesia pada periode 2009 - 2018.

\section{Metode Analisis}

Analisis empiris di dalam penelitian ini menggunakan Teknik regresi data panel untuk meng-investigasi pengaruh growth kepada profit. Dalam model regresi dinamis, lag dari variabel dependen dimasukan sebagai salah satu regressor. Model regresi data panel dinamis di dalam penelitian ini diestimasi dengan menggunakan metode Arellano Bond first difference GMM untuk mendapatkan estimasi yang konsisten dan efisien. Model dijelaskan dalam persamaan sebagai berikut:

$\pi_{i, t}=\alpha_{0}+Y_{i} \pi_{i, t-1}+\beta_{i} g_{i, t-1}+\beta_{2}$ control $_{i, t-1}+\epsilon_{i, t}$

Dimana:

$g_{i, t} \quad:$ Growth perusahaan i pada tahun $\mathrm{t}$

$\pi_{i, t} \quad$ : Profit perusahaan i pada tahun $\mathrm{t}$

Control : Variabel kontrol

$g_{i, t-1} \quad$ : Growth perusahaan i pada tahun t-1 (Lag)

$\pi_{i, t-1} \quad$ : Profit perusahaan i pada tahun t-1 (Lag)

Estimasi akan dilakukan dengan menggunakan dua model dengan variabel growth yang berbeda. Pada model pertama, variabel growth yang akan digunakan adalah growth in sales dan pada model kedua, variabel yang akan digunakan adalah growth in employee. Di dalam model juga akan dimasukkan dua variabel kontrol, yakni total aset dan juga debt to asset ratio. 


\section{HASIL DAN PEMBAHASAN}

\section{A. Analisis non-parametrik}

Analisis non-parametrik dengan menggunakan scatter plot dapat digunakan untuk memberikan gambaran mengenai hubungan antara dua variabel. Analisis non parametrik hanya memberikan gambaran kasar mengenai hubungan variabel akan tetapi tidak bisa menunjukkan arah kausalitas dari dua variabel (Coad 2007), analisis non parametrik dari kedua model dapat dilihat seperti dibawah ini:
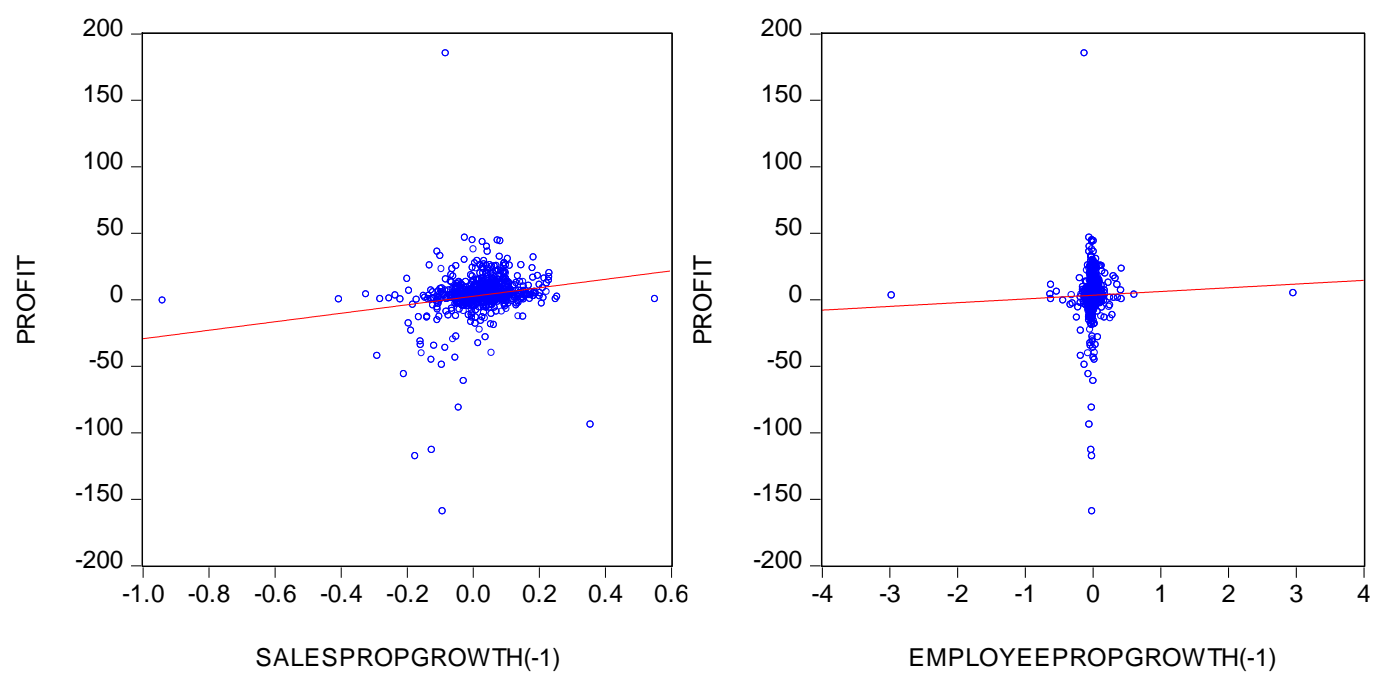

Secara umum, dari analisis scatter plot diatas tidak dapat menunjukkan dengan jelas mengenai pengaruh dari growth kepada profit, baik growth diukur dengan sales ataupun dengan employee. Pada scatter plot sales growth terhadap profit dapat dilihat bahwa sebaran data yang ada menunjukkan hubungan poisitf, akan tetapi banyak juga sebaran data ekstrim yang menunjukkan hubungan yang negatif. Pada scatter plot employee growth juga terjadi hal yang sama seperti scatter plot sales growth. akan tetapi dapat dikatakan bahwa sebaran pada employee growth lebih ekstrim jika dibandingkan dengan sales growth.

\section{B. Uji Kriteria Model}

Estimator GMM Arellano-Bond menghasilkan estimasi yang konsisten dan tidak bias, ketika $V_{i, t}$ tidak mengalami masalah korelasi serial dan memiliki variabel instrumental yang valid (Baltagi 2005). Metode estimasi data panel dinamis dengan estimator GMM Arellano-Bond dapat dikatakan baik apabila memenuhi kriteria vailidas instrumen dan konsisten. Untuk menguji validitas instrumen, Arellano \& Bond (1991) merekomendasikan uji Sargan. Sedangkan untuk mengukur kriteria konsisten digunakan Arellano-Bond serial correlation test (AR2). Tabel dibawah memaparkan hasil pengujian kriteria model pada model empiris yang digunakan di dalam penelitian ini. 
UJI KRITERIA MODEL GMM

\begin{tabular}{|c|c|c|c|c|}
\hline SERIAL - & Ordo 1 & m-statistic & -1.542877 & -1.489438 \\
\hline CORRELATION & & Prob. & 0.1229 & 0.1364 \\
\hline \multirow[t]{2}{*}{ TEST } & Ordo 2 & m-statistic & 1.321712 & 1.375631 \\
\hline & & Prob. & 0.1863 & 0.1689 \\
\hline \multirow[t]{2}{*}{ UJI SARGAN } & & J-statistic & 47.07745 & 47.48736 \\
\hline & & $\begin{array}{l}\text { Prob } \\
\text { statistic) }\end{array}$ & 0.083445 & 0.077456 \\
\hline
\end{tabular}

Berdasarkan tabel diatas dapat diketahui bahwa pada model 1 tidak terdapat serial korelasi baik pada ordo satu maupun ordo dua. Ordo satu menunjukkan nilai pvalue sebesar 0.1229 dan ordo dua menunjukkan nilai p-value sebesar 0.1863. Pada penelitian ini digunakan derajat kepercayaan sebesar 0.05. karena nilai p-value baik ordo satu maupun ordo dua lebih besar daripada 0.05 , maka estimasi dapat dikatakan konsisten karena tidak terjadi serial korelasi pada ordo pertama maupun ordo kedua. Selanjutnya, pengujian validitas penggunaan validitas instrumen dengan uji sargan dapat dilihat dari nilai p-value j-statistik. Pada model 1 , nilai $p$-value $\mathrm{j}$-statistik adalah sebesar 0.083445 , nilai tersebut lebih besar dari derajat kepercayaan 0.05 , hal ini memiliki arti bahwa kondisi overidentifying restriction valid sehingga tidak ada masalah validitas instrumen.

Pada pengujian kriteria untuk model 2 dapat diketahui bahwa tidak terdapat serial korelasi baik pada ordo satu maupun ordo dua. Ordo satu menunjukkan nilai pvalue sebesar 0.1364 dan ordo dua menunjukkan nilai p-value sebesar 0.1689. Pada penelitian ini digunakan derajat kepercayaan sebesar 0.05 . karena nilai p-value baik ordo satu maupun ordo dua lebih besar dari 0.05 maka estimasi model dapat dikatakan konsisten karena tidak terjadi serial korelasi pada ordo pertama maupun ordo kedua. Selanjutnya, pengujian validitas instrumen dengan menggunakan uji sargan dapat dilihat dari nilai $\mathrm{p}$-value $\mathrm{j}$-statistik. Pada model 2 , nilai $\mathrm{p}$-value $\mathrm{j}$-statistik adalah sebesar 0.077456 , nilai tersebut lebih besar dari derajat kepercayaan 0.05 yang berarti kondisi overidentifying restriction valid dan dapat dikatakan tidak ada masalah validitas instrumen.

\section{Hasil Estimasi Generalized Method of Moment (GMM)}




Model Pertama
\begin{tabular}{|l|l|l|l|l|}
\hline Variabel & Koefisien & Std.Error & t-statistic & Prob. \\
\hline Profit(-1) & 0.106514 & 0.002761 & 38.57205 & 0.0000 \\
\hline Sales Growth(-1) & -8.146370 & 0.950208 & -8.573251 & 0.0000 \\
\hline Asset(-1) & -4.597911 & 1.093695 & -4.204012 & 0.0000 \\
\hline Debtratio(-1) & 1.0050337 & 1.136668 & 9.240393 & 0.0000 \\
\hline J-statistic & \multicolumn{5}{|c|}{47.07745} & \\
\hline Prob (j-statistic) & & & 0.083445 & \\
\hline Prob Wald Test & - & - & & \\
\hline Observations & & & & \\
\hline $\begin{array}{l}\text { Cross-section } \\
\text { included }\end{array}$ & & & & \\
\hline
\end{tabular}

\begin{tabular}{|} 
Model Kedua \\
\begin{tabular}{|l|l|l|l|l|}
\hline Variabel & Koefisien & Std.Error & t-statistic & Prob. \\
\hline Profit(-1) & 0.101495 & 0.002122 & 47.82588 & 0.0000 \\
\hline $\begin{array}{l}\text { Employee } \\
\text { Growth(-1) }\end{array}$ & -0.148020 & 0.528936 & -0.279845 & 0.7797 \\
\hline Asset(-1) & -4.694114 & 1.015071 & -4.624419 & 0.0000 \\
\hline Debtratio(-1) & -1.041008 & 1.120058 & 9.294240 & 0.0000 \\
\hline J-statistic & & & 47.48736 & \\
\hline Prob (j-statistic) & & & 0.077456 & \\
\hline Prob Wald Test & - & - & & \\
\hline Observations & & & 656 & \\
\hline $\begin{array}{l}\text { Cross-section } \\
\text { included }\end{array}$ & & & & \\
\hline
\end{tabular}
\end{tabular}

\section{Interpretasi Hasil}

Hasil estimasi pada model pertama menunjukkan bahwa sales growth berpengaruh negatif terhadap profit ( $\mathrm{t}$ hitung $8.573251>\mathrm{t}$ tabel 1.65 pada tingkat keyakinan 95 persen) dimana setiap peningkatan sales growth sebesar 1 persen, maka akan menurunkan profit sebesar -8.146370 persen, dengan asumsi ceteris paribus. Variabel kontrol pada model pertama memberikan pengaruh yang berbeda. Pada model pertama, variabel total aset berpengaruh negatif signifikan terhadap profit perusahaan (t hitung $4.204012>\mathrm{t}$ tabel 1.65, pada tingkat keyakinan 95 persen) Dimana setiap kenaikan satu persen total aset maka akan menurunkan profit sebesar -4.694114 persen dengan asumsi ceteris paribus. Sedangkan debt to asset ratio memberikan pengaruh positif dan signifikan kepada profit (t hitung $9.240393>\mathrm{t}$ tabel 1.65, pada tingkat keyakinan 95 persen), dimana setiap kenaikan satu persen dari debt to asset ratio akan 
menaikkan profit perusahaan sebesar 1.0050337 persen, dengan asumsi ceteris paribus.

Hasil estimasi pada model kedua menunjukkan hasil yang tidak berbeda jauh, growth yang diukur dengan employee growth memberikan pengaruh negatif dan tidak signifikan kepada profit (t hitung $0.279845<\mathrm{t}$ tabel 1.65 pada tingkat keyakinan 95 persen), dimana setiap peningkatan employee growth sebesar satu persen akan menurunkan profit sebesar -0.148020 persen, ceteris paribus. Variabel kontrol pada model kedua menunjukkan hasil yang berbeda dengan model pertama. Pada model kedua, variabel kontrol total aset memberikan pengaruh negatif dan signifikan kepada profit (t hitung $4.624419>\mathrm{t}$ tabel 1.65, pada tingkat keyakinan 95 persen) dimana kenaikan satu persen pada total aset akan menurunkan profit sebesar -4.694114 persen, dengan asumsi ceteris paribus. Debt to asset ratio memberikan pengaruh negatif signifikan kepada profit (t hitung 1.041008 > t tabel 1.65, [ada tingkat keyakinan 95 persen) dimana kenaikan satu persen pada debt to asset ratio akan menurunkan profit sebesar -1.041008 persen.

\section{E. Pembahasan Hasil Temuan Empiris}

Penelitian ini memeriksa bagaimana pengaruh growth kepada profit perusahaan. Growth diukur dengan menggunakan dua variabel yakni sales growth dan employee growth. Hasil estimasi pada model pertama, menunjukkan bahwa growth yang diukur dengan sales growth berpengaruh negatif dan signifikan terhadap profit perusahaan. Sedangkan pada model kedua growth yang diukur dengan employee growth juga memberikan pengaruh negatif akan tetapi tidak signifikan kepada profit perusahaan.

Hasil temuan empiris mendukung hipotesis kaum behavioral yang memprediksikan bahwa growth akan memberikan pengaruh negatif kepada profit perusahaan. Pengaruh negatif dari growth kepada profit yang terjadi bisa saja disebabkan karena terjadinya penrose effect, Batasan manajerial, principal agent problem atau mungkin diseconomies of scale, yang membuat cost perusahaan membengkak dan mengurangi tingkat profit.

Temuan empiris pada penelitian ini sejalan dengan penelitian yang dilakukan oleh Jang \& Park (2011) yang menemukan bahwa growth perusahaan akan memberikan pengaruh negatif kepada profit perusahaan. Penelitian yang dilakukan oleh Goddard, Molyneux, and Wilson (2004), juga menunjukkan hasil yang sama, bahwa growth saat ini akan menyebabkan tingkat profit di masa yang akan datang berkurang jika pada jangka pendek perusahahaan mengalami tingkat growth yang terlalu cepat.

Growth yang diukur dengan employee growth memberikan pengaruh negatif dan tidak signifikan. Hal ini bisa jadi dikarenakan perbedaan kondisi institusional yang berada di setiap negara (Lee 2014). Carrizosa (2006), mengungkapkan bahwa employee growth adalah variabel terbaik untuk mengukur growth perusahaan karena 
employee growth dapat menggambarkan proses internal perusahaan dan juga karena employee growth tidak sensitif terhadap inflasi dan nilai tukar. Akan tetapi, di Indonesia sendiri, inflasi berperan besar dalam menentukkan tingkat upah minimum, yang berarti untuk kasus di Indonesia, employee growth justru sensitif terhadap inflasi. Jadi ada kemungkinan bahwa employee growth yang berubah setiap tahunnya bukan terjadi karena proses internal, akan tetapi karena faktor eksternal di luar kendali perusahaan.

Diluar pembahasan mengenai temuan inti yakni pengaruh growth kepada profit, penelitian ini menemukan beberapa temuan lainnya. Yakni pengaruh dari variabel kontrol debt to asset ratio dan juga total aset kepada profit. Variabel kontrol debt to asset ratio memberikan pengaruh yang tidak konsisten. Pada model pertama memberikan pengaruh positif signifikan dan pada model kedua memberikan pengaruh negatif signifikan. Sedangkan variabel total aset memberikan pengaruh negatif dan signifikan kepada profit pada estimasi model pertama maupun estimasi model kedua.

\section{KESIMPULAN}

Penelitian ini bertujuan untuk mengkaji pengaruh dari growth kepada profit pada perusahaan manufaktur terbuka di Indonesia periode tahun 2009 sampai dengan tahun 2018. Sebelumnya, terjadi perdebatan baik secara teoritis maupun hasil empiris mengenai pengaruh dari growth kepada profit. Hasil penelitian empiris Cowling (2004), Coad (2007), (2010), Coad et al. (2011) dan (Lee 2014) menunjukkan hasil yang mendukung hipotesis kaum klasik bahwa growth akan memberikan pengaruh positf kepada profit. Sedangkan, hasil empiris dari Goddard, Molyneux, and Wilson (2004), Jang \& Park (2011) menunjukkan hasil yang mendukung hipotesis kaum behavioral bahwa growth akan memberikan pengaruh negatif kepada profit.

Hasil uji empiris pada penelitian ini mendukung hipotesis kaum behavioral. Berdasarkan estimasi GMM pada model pertama dan model kedua, variabel growth yang di ukur dengan growth in sales dan growth in employee memberikan pengaruh negatif kepada profit perusahaan. Pengaruh negatif ini merupakan indikasi terjadinya Penrose effect, principal agent problem, Batasan manajerial atau terjadinya diseconomies of scale yang membuat cost perusahaan menjadi tidak efisien dan akhirnya mengurangi tingkat profit perusahaan.

Hasil temuan empiris memberikan implikasi bahwa untuk perusahaan manufaktur terbuka di Indonesia lebih baik tidak menerapkan strategi growth untuk mencapai tingkat profit yang lebih tinggi. Karena berdasarkan hasil empiris ditunjukkan bahwa growth akan memberikan pengaruh negatif kepada profit perusahaan. Strategi selain growth yang bisa diterapkan dapat berupa strategi marketing atau strategi sumber daya manusia.

\section{DAFTAR PUSTAKA}

Arellano, Manuel, and Stephen Bond. 1991. "Some Tests of Specification for Panel Data: Monte Carlo Evidence and an Application to Employment Equations." The Review of Economic Studies 58 (2): 277. https://doi.org/10.2307/2297968. 
Arellano, M. (1987). PRACTITIONERS' CORNER: Computing Robust Standard Errors for Within-groups Estimators. Oxford Bulletin of Economics and Statistics, 49(4), 431-434. https://doi.org/10.1111/j.14680084.1987.mp49004006.x

Amato, L., \& Wilder, R. P. (1985). The Effects of Firm Size on Profit Rates in U. S. Manufacturing. Southern Economic Journal, 52(1), 181. https://doi.org/10.2307/1058913

Baltagi, Badi. 2005. Econometric Analysis of Panel Data. Third. John Wiley \& Sons, Ltd.

Brue, Stanley, and Randy Grant. 2007. The Evolution of Economic Thought. Eight Edit. Mason, Ohio: South-Western Cengage Learning.

Carrizosa, Mercedes Teruel. 2006. "Firm Growth, Persistence And Multiplicity Of Equilibria: An Analysis Of Spanish Manufacturing And Service Industries." International Standard Book Number (ISBN), 23-92. https://www.tesisenred.net/bitstream/handle/10803/8447/Chapter4.pdf?sequenc $\mathrm{e}=13 \&$ isAllowed $=\mathrm{y}$.

Case, K., \& Fair, R. (2007). Prinsip - Prinsip Ekonomi. New Jersey: Penerbit Erlangga.

Chan, James, and Chris Murphy. 2019. "Theory of The Firm.” 2019. https://www.investopedia.com/terms/t/theory-firm.asp.

Coad, Alex. 2007. "Testing the Principle of 'Growth of the Fitter': The Relationship between Profits and Firm Growth." Structural Change and Economic Dynamics 18 (3): 370-86. https://doi.org/10.1016/j.strueco.2007.05.001.

Coad, Alex. 2010. "Exploring the Processes of Firm Growth: Evidence from a Vector Auto-Regression." Industrial and Corporate Change 19 (6): 1677-1703. https://doi.org/10.1093/icc/dtq018.

Coad, Alex, and Werner Hölzl. 2012. "Firm Growth: Empirical Analysis." Handbook on the Economics and Theory of the Firm, 324-38. https://doi.org/10.4337/9781781002407.00035.

Coad, Alex, Rekha Rao, and Federico Tamagni. 2011. "Growth Processes of Italian Manufacturing Firms." Structural Change and Economic Dynamics 22 (1): 5470. https://doi.org/10.1016/j.strueco.2010.09.001.

Cowling, Marc. 2004. "The Growth - Profit Nexus." Small Business Economics 22 (1): 1-9. https://doi.org/10.1023/B:SBEJ.0000011568.42714.c9. 
Cubbin, J., \& Leech, D. (1986). Growth versus Profit-Maximization: Sumultaneousequations Approach to Testing the Marris Model. Managerial and Decision Economics, 7, 123-131.

Flannery, M. J., \& Hankins, K. W. (2013). Estimating dynamic panel models in corporate finance. Journal of Corporate Finance, 19(1), 1-19. https://doi.org/10.1016/j.jcorpfin.2012.09.004

Fuertes-Callén, Y., \& Cuellar-Fernández, B. (2019). Inter-Relationship Between Firm Growth and Profitability in a Context of Economic Crisis. Journal of Business Economics and Management, 20(1), 86-106. https://doi.org/10.3846/jbem.2019.6928

Goddard, John A., Philip Molyneux, and John O. S. Wilson. 2004. "Dynamics of Growth and Profitability in Banking." Journal of Money, Credit, and Banking 36 (6): 1069-90. https://doi.org/10.1353/mcb.2005.0015.

Gruenwald, R. K. (2015). Measuring growth of the firm : Theoretical considerations. International Business and Global Economy, 1(2), 121-131.

Gujarati, D., \& Porter, D. (2009). Basic Econometrics. New York: Mcgraw-Hill Irwin.

GUPTA, VINOD K. 1981. "Minimum Efficient Scale As a Determinant of Concentration: A Reappraisal.” The Manchester School 49 (2): 153-64. https://doi.org/10.1111/j.1467-9957.1981.tb00943.x.

Jang, Soo Cheong (Shawn), and Kwangmin Park. 2011. "Inter-Relationship between Firm Growth and Profitability." International Journal of Hospitality Management 30 (4): 1027-35. https://doi.org/10.1016/j.ijhm.2011.03.009.

Lee, Sanghoon. 2014. "The Relationship between Growth and Profit: Evidence from Firm-Level Panel Data." Structural Change and Economic Dynamics 28: 1-11. https://doi.org/10.1016/j.strueco.2013.08.002.

Lipczynski, John. 2005. Industrial Organization Industrial Organization. Second. Edinburgh: Pearson Education Limited.

Pindyck, R., \& Rubinfeld, D. (2009). Microeconomics (Ninth). Edinburgh: Pearson Education Limited.

Reeb, D., Sakakibara, M., \& Mahmood, I. P. (2012). From the editors: Endogeneity in international business research. Journal of International Business Studies, 43(3), 211-218. https://doi.org/10.1057/jibs.2011.60 
Samuelson, P., \& Nordhaus, W. (2005). Economics (eighteenth). New York: The Mcgraw- Hill Companies.

Ullah, S., Akhtar, P., \& Zaefarian, G. (2018). Dealing with endogeneity bias: The generalized method of moments (GMM) for panel data. Industrial Marketing Management, 71(November), 69-78.

https://doi.org/10.1016/j.indmarman.2017.11.010

Yarrow, G. K. (1976). On the Predictions of Managerial Theories of the Firm. The Journal of Industrial Economics, 24(4), 267. https://doi.org/10.2307/2098158 